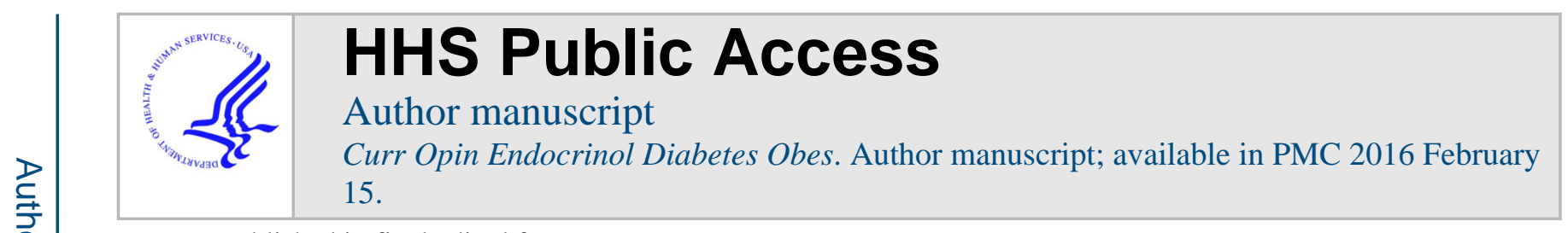

Published in final edited form as:

Curr Opin Endocrinol Diabetes Obes. 2012 April ; 19(2): 128-135. doi:10.1097/MED. 0b013e328350a6e1.

\title{
Type 2 diabetes and bone fractures
}

\author{
Kendall F. Moseley \\ Division of Endocrinology, Johns Hopkins Bayview Medical Center, Baltimore, Maryland, USA
}

\begin{abstract}
Purpose of review-To discuss current literature and hypotheses pertaining to the pathophysiology of increased bone fragility and fracture in men and women with type 2 diabetes mellitus.
\end{abstract}

Recent findings-Despite high bone mineral density, studies have shown that men and women with type 2 diabetes mellitus (T2DM) are at increased risk for fracture. Complications of T2DM including retinopathy and autonomic dysfunction may contribute to bone fracture by increasing fall risk. Nephropathy may lead to renal osteodystrophy. Lean mass and potentially fat mass, may additionally contribute to skeletal health in diabetes. There is increasing acknowledgement that the marrow microenvironment is critical to efficient bone remodeling. Medications including thiazolidinediones and selective serotonin reuptake inhibitors may also impair bone remodeling by acting on mesenchymal stem cell differentiation and osteoblastogenesis. T2DM is associated with significant alterations in systemic inflammation, advanced glycation end-product accumulation and reactive oxygen species generation. These systemic changes may also directly and adversely impact the remodeling cycle and lead to bone fragility in T2DM, though more research is needed.

Summary-Fracture is a devastating event with dismal health consequences. Identifying the extrinsic and intrinsic biochemical causes of bone fracture in T2DM will speed the discovery of effective strategies for fracture prevention and treatment in this at-risk population.

\section{Keywords}

bone mineral density; fracture; mesenchymal stem cell; type 2 diabetes mellitus

\section{INTRODUCTION}

Skeletal fracture is a devastating event with dismal health consequences. More than 250000 hip fractures occur annually in older adults in the USA, and are associated with $25 \%$ risk of mortality in the year following fracture [1,2"]. For those who survive, their lives may be additionally complicated by loss of independence, financial hardship, as well as an increased overall risk of death [3-5]. All fractures -hip, vertebral and nonvertebral - carry with them significant morbidity and heightened risk for future fracture [6"']. As the population ages, identification of those at risk and early intervention to prevent fracture is imperative. The

Correspondence to Kendall F. Moseley, MD, 5200 Eastern Avenue, MFL Building, Center Tower, Suite 4300, Baltimore, MD 21224 , USA. Tel: +1 410550 6497; fax: +1 4105506864 ; kmosele4@jhmi.edu.

Conflicts of interest

No potential conflicts of interest or financial disclosures relevant to this article were reported. 
urgency is highlighted all the more by looming healthcare costs. It is estimated that fracturerelated costs exceed US\$ 20 billion annually, a number that will only rise in the years to come $[7,8]$. There is no question that bone fractures will continue to be an important topic in clinical investigation and future healthcare debates.

Traditionally, fracture risk is determined using dual X-ray absorptiometry techniques (DXA), which provide real, or two-dimensional, bone mineral density (BMD) measurements at the spine and hip. Definitions of normal, low BMD ('osteopenia') and osteoporosis stem from these BMD measurements [1]. Lower BMD predicts increased fracture risk in aging populations, as parameters of low bone quantity are highly correlated with bone strength and fracture susceptibility. In 2008, a new fracture prediction tool, or FRAX (http:// www.shef.ac.uk/FRAX/), was introduced by the WHO in an attempt to predict fracture risk with even greater accuracy [9]. Taking other risk factors for osteoporosis and fracture into account (age, family history, weight, etc.), use of FRAX has become more widespread in primary care and metabolic bone clinics alike to assist physicians in managing those at risk for fracture.

\section{TYPE 2 DIABETES MELLITUS AND BONE MINERAL DENSITY}

Men and women with type 2 diabetes mellitus (T2DM) typically have normal to high BMD compared with their age-matched healthy peers $[10,11]$. Several factors likely contribute to this observation. BMD is strongly associated with body weight, and low BMI is as a known risk factor for the development of osteoporosis and fracture [12,13]. Conversely, persons of higher weights such as those with the T2DM will have higher BMD compared with agematched controls. In part, increased BMD in those with T2DM may represent biomechanical adaptation to greater loads placed on the skeleton $[14,15]$. Lean mass, often increased in proportion to weight gain, places biomechanical strain on bone and can potentiate bone formation in T2DM [16]. Insulin is anabolic to bone, and the hyperinsulinemic states associated with T2DM may also promote skeletal acquisition [17,18]. It should be noted that the finding of increased BMD in men and women with T2DM is in stark contrast to the low BMD of those with type 1 diabetes (T1DM). An autoimmune disease of insulin deficiency, T1DM is often accompanied by nutritional deficits, low body weight and other factors, which cause impaired bone formation and decreased BMD [19,20].

\section{TYPE 2 DIABETES MELLITUS AND FRACTURE}

Paradoxically, despite elevations in BMD, which should portend increased skeletal strength, men and women with T2DM are at an increased risk of fracture [21-23]. In the Rotterdam Study, consisting of a large cohort study of 6655 men and women (ages 255), nonvertebral fracture risk was increased for patients with T2DM (HR 1.33) compared with weight and age-matched controls [24]. These finding are further supported in other longitudinal investigations. Women 65 years or older in the Study of Osteoporotic Fractures with T2DM were at an increased risk of hip fracture [relative risk (RR) 1.82], as well as proximal humerus and foot fractures [25]. In the men and women (ages 70-79 years) of the Health Aging and Body Composition study, T2DM was associated with accelerated bone loss at the hip, as well as an increased risk of overall fracture (RR 1.64) even after adjustment for hip 
BMD [26]. In the Nurse's Health Study, the age-adjusted RR of hip fracture was $70 \%$ greater in women aged 34-59 years with T2DM compared with those without diabetes [27]. These abundant data highlight the discrepancy between bone quantity, as measured by DXA, and bone quality and the capacity to withstand fracture in T2DM. The pathophysiology of the increased fracture risk in T2DM remains under investigation, though likely stems from numerous conditions associated with diabetes that have detrimental effects on the skeleton (Fig. 1).

\section{MEDICATIONS}

Thiazolidinediones (TZDs) have long been used in persons with T2DM as an oral medication to promote insulin sensitivity though activation of the nuclear receptor, peroxisome proliferator-activated receptor $\gamma$ [28]. Among the many controversies encountered by this class of drugs has been their adverse effects on the skeleton [29]. Randomized controlled trials have shown that TZDs are associated with significant bone loss [30",31]. In A Diabetes Outcome Progression Trial, premenopausal and postmenopausal women treated with rosiglitazone were at twice the risk for fracture compared with those taking metformin or glyburide [32]. A similar increase in fracture risk has been reported in those taking pioglitazone [33]. Mechanistically, glitazones promote the differentiation of the bone's pluripotent, mesenchymal stem cells (MSCs) into adipocytes rather than bonebuilding osteoblasts. TZDs may also have adverse effects on circulating hormones that are anabolic to bone by decreasing insulin-like growth factor 1 (IGF-1) and estrogen levels [34]. Recognized now as a consequence and possible precipitant of T2DM is clinical depression, commonly treated with selective serotonin reuptake inhibitors (SSRIs) [35,36]. Of the many recent and exciting discoveries in the bone field, serotonin and bone metabolism appear linked [37]. Gut-derived serotonin reduces osteoblast proliferation and the accrual of bone mass [38,39"]. There has, therefore, been some concern that medications used to antagonize the serotonin transport protein and increase local serotonin activity could have negative implications for bone health. Indeed, several cross-sectional and longitudinal studies have shown associations between SSRI use and bone loss [40-42]. Fracture rates, too, appear to be increased in users of SSRIs compared with nonusers in clinical and prospective studies $[43,44]$. Because serotonin may also have positive effects on bone mass via activity in the central nervous system, additional investigation is needed to determine the net effect of SSRIs on bone strength $\left[38,39^{\mathbf{*}}, 45^{\mathbf{\prime \prime}}\right]$.

\section{COMPLICATIONS OF TYPE 2 DIABETES MELLITUS}

With the progression of T2DM, both microvascular and macrovascular complications often arise. These complications of longstanding T2DM have definite implications for bone density and strength [46"]. Men and women with T2DM are at an increased risk for falls when compared with those without diabetes [47]. Whereas hypoglycemic episodes may lead directly to syncopal events, gait instability due to autonomic neuropathy and orthostatic hypotension, peripheral neuropathy and retinopathy can also lead to falls [23,47]. Renal dysfunction leads to secondary hyperparathyroidism and bone loss via accelerated skeletal resorption and mineralization defects. Persistently elevated blood glucose levels can lead to renal calcium losses that are not appropriately corrected though elevations in parathyroid 
hormone, termed 'functional hypoparathyroidism' [48]. The microvascular disease that accompanies T2DM may also impair blood flow to the marrow microenviroment and alter local remodeling, though these processes remain under investigation [49"',50-52].

\section{HORMONAL ALTERATIONS}

Although insulin is anabolic to bone, there are several hormonal disturbances associated with insulin resistance, metabolic syndrome and T2DM that have negative repercussions on bone integrity. IGF-1 is one of many positive regulators of bone metabolism and may be lower in persons with diabetes $[53,54]$. Further, serum IGF-1 levels have been reported as inversely associated with the presence of vertebral fractures in postmenopausal women with T2DM [55"]. Testosterone is also anabolic to bone primarily through its aromatization to estrogen in adipose tissue [56]. Low testosterone in the setting of low or inappropriately normal lutenizing hormone and follicle-stimulating hormone is common in the diabetic population and may contribute to impaired bone strength in this population [57-59]. Vitamin D deficiency, associated not only with increased fall risk and fracture in older individuals, is extremely common in men and women with T2DM $[60,61]$. Sequestered in adipose stores as a fat-soluble vitamin, insufficient levels of both local and circulating vitamin D may lead to osteomalacia, secondary hyperparathyroidism and accelerated bone loss [62,63]. When coupled with renal dysfunction that impairs the conversion of 25 -hydroxyvitamin D to 1,25 dihydroxyvitamin $\mathrm{D}$, the effects on bone metabolism in T2DM can be severe.

\section{BODY COMPOSITION}

Although higher BMI is typically associated with higher BMD, it is important to consider the components of body mass - lean, fat and skeletal. When evaluating lean and fat mass separately, lean mass appears most critical in determining bone mass throughout the life cycle $[64,65]$. The biomechanical forces of muscle activity on bone promote bone remodeling. Thus, lean mass is a positive determinant of BMD [66]. Men and women with osteoporosis are routinely advised to increase the time they spend performing resistance and weight-bearing exercise to capitalize on the influence of lean mass on osteoblast activity [67]. In T2DM, lean mass is positively associated with both BMD and parameters of hip geometry including buckling ratio and section modulus, surrogate measures of hip strength [68"',69"']. Declines in lean mass with progressive insulin resistance, termed 'sarcopenic obesity', may, therefore, have immediate implications for bone quality in T2DM [70"-,71].

The effects of fat mass on bone density and strength are less clear. Some investigators have reported significant associations between fat mass and bone density in older men and women [72-75]. In women with noninsulin requiring diabetes mellitus, fat mass is associated with bone density and hip strength $\left[68^{-"}, 69^{\prime \prime}\right]$. The association was not significant in men. With the recognition that adipose is, in fact, an endocrine organ, there has been increased interest in the effects of adipokines as mediators of bone metabolism [76]. Leptin and adiponectin affect both bone formation and bone resorption and have been proposed as mediators of a fat-bone association. Leptin promotes osteoblast differentiation and proliferation while diminishing osteoclast recruitment [77-79]. In the central nervous system, leptin may have a catabolic effect on bone through its interactions with insulin 
secretion and neuropeptides $[80,81]$. Adiponectin, produced in visceral, subcutaneous and bone marrow fat, has been shown to be downregulated in diabetes and obesity $[82,83]$. Like leptin, its effects on bone may be mixed, promoting osteoblastogenesis, whereas inhibiting osteoprotegerin and thus bolstering osteoclastogenesis [84]. The potentially independent effects of body composition on bone density will be a promising area of research in the future given that it can be modified in men and women with T2DM.

\section{NOVEL MEDIATORS OF BONE METABOLISM AND FRACTURE}

T2DM represents a state of multisystem homeostatic disruption. Many of the systemic changes associated with T2DM have detrimental local effects on the skeleton. These more novel mediators of skeletal metabolism, though not entirely understood, require some attention. Increased with aging and T2DM, circulating advanced glycation end products (AGEs) interfere with collagen cross-links in bone and can cause structural incompetence $\left[85,86,87^{\mathbf{}}\right]$. Both serum and urine pentosidine, an AGE, are associated with an increased clinical fracture risk in men and women with T2DM $[88,89]$. At the level of the bone marrow microenvironment, altered systemic factors in T2DM may have additional adverse effects in the bone remodeling cycle. As noted, MSCs are important determinants of bone quality given their capacity to differentiate into bone-building osteoblasts versus adipocytes $[90,91]$. The proliferation and differentiation of these osteogenic cells are dependent on extrinsic and intrinsic factors. Locally, osteocyte signaling, inflammatory cytokines, growth factors, reactive oxygen species and other signaling molecules contribute to MSCs' activity [92-94]. The MSCs are also continually bathed in systemic, circulating factors, which flow freely into the bone microenvironment through the sinusoidal circulation. In T2DM, fluctuations in systemic factors including anabolic hormones, AGEs, inflammatory cytokines and oxidative stressors have the potential to directly and adversely influence MSCs' activity with downstream effects on skeletal fragility [95"',96-98]. The interplay of the bone microenvironment, MSCs' activity and fragility in the diabetic skeleton is currently unknown.

\section{FRACTURE RISK ASSESSMENT IN TYPE 2 DIABETES MELLITUS}

The underpinnings of bone fragility in T2DM are unquestionably multifactorial, making assessment for fracture risk in those with glucose intolerance all the more challenging. To date, screening for increased fracture risk and initiation of osteoporosis treatment are based on BMD measurements. Unfortunately, older adults with T2DM fracture despite normal BMD. Though studies have shown that persons with T2DM who sustain fractures do so at a lower BMD than diabetic patients who do not, the majority of these fractures occur despite what physicians would consider 'normal BMD'. Thus, BMD alone is not an adequate determinant of fracture risk in men and women with deranged glucose homeostasis. Traditional DXA measurements fail to accurately predict fracture in this at-risk population. FRAX calculations that take into account factors for bone fragility in addition to BMD may also underestimate fracture risk in T2DM [99].

Although bone biopsy is the gold standard in defining causation of idiopathic fracture, the procedure is both invasive and impractical as an osteoporosis screening tool in persons with 
T2DM [100]. Rather, with the advent of new technologies, there has been some hope that alternative imaging techniques will cast light on the cause of bone fractures in T2DM and lead to improved osteoporosis prevention and screening. In the research setting, high resolution peripheral quantitative computed tomography (HR-pQCT) enables investigators to quantify trabecular and cortical bone microarchitecture in the radius and tibia [101,102]. Unfortunately, this noninvasive measure of bone microarchitecture does not appear to correlate with the gold standard, or histomorphometry from bone biopsy. Cohen et al. [103"] compared in-vivo HR-pQCT of the tibia and radius to histomorphometry of transiliac bone biopsies in 54 premenopausal women with idiopathic fracture. Only two measures of bone quantity were significantly correlated, including trabecular bone volume $(r=0.30)$ and cortical thickness $(r=0.36)$. There were no significant correlations between measures of bone quality including trabecular number, thickness or spacing. Using HR-pQCT, Burghardt et al. [104"] additionally reported that cortical microarchitecture may be compromised in patients with T2DM. However, without clear correlation of data acquired from this imaging technique with bone biopsy, clinical use of HR-qQCT will be limited. Microindentation, a technique in which a small probe inserted into the tibia to displace periosteum, shows promise in quantifying the toughness of bone, or its susceptibility to microfracture [105"']. There have been no reported studies, however, utilizing this technology in T2DM.

Many of the remaining and less-invasive techniques for measuring bone strength and remodeling are similarly inadequate in those with T2DM. In a recently published study, calcaneal quantitative ultrasound was not significantly associated with the presence of vertebral fractures in patients with T2DM [106]. Markers of bone resorption and formation, or bone turnover markers, measured in blood and urine samples also appear to have limited utility in determination of T2DM fracture risk. C-telopeptide and osteocalcin are markers of bone resorption, while procollagen $1 \mathrm{~N}$-terminal peptide is a marker of bone formation. Some studies have shown that markers of both bone resorption and formation are low in T2DM, suggestive of impaired remodeling [107-109]. However, these data are conflicting and prevent applicability of bone turnover testing to fracture risk assessment in T2DM.

\section{FRACTURE PREVENTION AND TREATMENT IN TYPE 2 DIABETES MELLITUS}

As with any disease process, prevention and treatment rest heavily on an understanding of the pathophysiology of the disease. Fracture in T2DM is no different. As this rich area of research casts light on why persons with T2DM break bones despite normal BMD, modalities of fracture prevention and treatment will grow. Without question, modification of the known risk factors for bone loss and fragility should be implemented in T2DM. Glycemic control to prevent end-organ damage has important implications for the skeleton, potentially reducing falls and renal osteodystrophy. Screening for vitamin D deficiency should be employed in men and women with T2DM. Vitamin D should be replaced, as needed, to prevent osteomalacia and secondary hyperparathyroidism. The importance of a diet high in calcium and vitamin $\mathrm{D}$, as well as weight-bearing exercise, stressed most commonly in those with metabolic bone disease, should also be discussed with T2DM patients. Medications that might adversely impact the skeleton should be prescribed with 
some caution, the risks and the benefits of drug initiation carefully weighed. There is no prospective data in the literature to show that the use of antiresorptive or anabolic therapy will prevent future fractures in those with T2DM and normal BMD. Retrospectively, studies have shown that antiresorptive therapy worked equally well in reducing fracture risk in diabetic and nondiabetic patients [110"]. However, this group did not report baseline BMD or indication for drug initiation in either group, preventing generalizability of the conclusions to those with T2DM and normal BMD. Without a better understanding of the changes in bone quality and strength in T2DM, treating persons with gycemic derangement and normal BMD is difficult to justify.

\section{CONCLUSION}

Additional research in men and women with T2DM will provide the basis for determining when and how to screen those at risk for fracture beyond BMD measurement. This knowledge will assist physicians in deciding when to initiate treatment to prevent fracture in T2DM and which existing therapy will best treat fragility when it occurs. Insight into declines of bone quality in persons with T2DM will one day guide disease-specific interventions. This may mean that physicians will one day treat persons with T2DM and normal BMD to prevent fracture. This paradigm shift may be necessary in this at-risk population in whom BMD measurements are falsely reassuring.

\section{Acknowledgments}

Dr K.M. is supported on a Johns Hopkins University School of Medicine Clinician Scientist Career Development Award, a Grant for Early Medical/Surgical Subspecialists' Transition to Aging Research (1R03AG040695-01), and is an investigator on a Maryland Stem Cell Research Commission Award.

\section{REFERENCES AND RECOMMENDED READING}

Papers of particular interest, published within the annual period of review, have been highlighted as:

- of special interest

- of outstanding interest

Additional references related to this topic can also be found in the Current World Literature section in this issue (p. 146).

1. Dawson-Hughes B, Tosteson AN, Melton LJ 3rd, et al. Implications of absolute fracture risk assessment for osteoporosis practice guidelines in the USA. Osteoporos Int. 2008; 19:449-458. [PubMed: 18292975]

2-. Looker AC, Dawson-Hughes B, Tosteson AN, et al. Hip fracture risk in older US adults by treatment eligibility status based on new National Osteoporosis Foundation guidance. Osteoporos Int. 2010; 22:541-549. Updated guidelines based on the National Health and Nutrition Examination Survey II data demonstrating that men and women eligible for osteoporosis treatment are five times more likely to experience hip fracture. [PubMed: 20480142]

3. Leibson CL, Tosteson AN, Gabriel SE, et al. Mortality, disability, and nursing home use for persons with and without hip fracture: a population-based study. J Am Geriatr Soc. 2002; 50:1644-1650. [PubMed: 12366617]

4. Tosteson AN, Gabriel SE, Grove MR, et al. Impact of hip and vertebral fractures on quality-adjusted life years. Osteoporos Int. 2001; 12:1042-1049. [PubMed: 11846331] 
5. Arinzon Z, Fidelman Z, Zuta A, et al. Functional recovery after hip fracture in old-old elderly patients. Arch Gerontol Geriatr. 2005; 40:327-336. [PubMed: 15814166]

6-". Gulcelik NE, Bayraktar M, Caglar O, et al. Mortality after hip fracture in diabetic patients. Exp Clin Endocrinol Diabetes. 2011; 119:414-418. Men and women with T2DM are at an increased risk of mortality following hip fracture compared with those who do not have diabetes. [PubMed: 21553363]

7. Melton LJ 3rd, Gabriel SE, Crowson CS, et al. Cost-equivalence of different osteoporotic fractures. Osteoporos Int. 2003; 14:383-388. [PubMed: 12730750]

8. Tosteson AN, Melton LJ 3rd, Dawson-Hughes B, et al. Cost-effective osteoporosis treatment thresholds: the United States perspective. Osteoporos Int. 2008; 19:437-447. [PubMed: 18292976]

9. Dawson-Hughes B, Looker AC, Tosteson AN, et al. The potential impact of new National Osteoporosis Foundation guidance on treatment patterns. Osteoporos Int. 2010; 21:41-52. [PubMed: 19705046]

10. van Daele PL, Stolk RP, Burger H, et al. Bone density in noninsulin-dependent diabetes mellitus. The Rotterdam Study. Ann Intern Med. 1995; 122:409-414. [PubMed: 7856988]

11. Rakic V, Davis WA, Chubb SA, et al. Bone mineral density and its determinants in diabetes: the Fremantle Diabetes Study. Diabetologia. 2006; 49:863-871. [PubMed: 16518589]

12. De Laet C, Kanis JA, Oden A, et al. Body mass index as a predictor of fracture risk: a metaanalysis. Osteoporos Int. 2005; 16:1330-1338. [PubMed: 15928804]

13. Ooms ME, Lips P, Van Lingen A, et al. Determinants of bone mineral density and risk factors for osteoporosis in healthy elderly women. J Bone Miner Res. 1993; 8:669-675. [PubMed: 8328308]

14. Duan Y, Beck TJ, Wang XF, et al. Structural and biomechanical basis of sexual dimorphism in femoral neck fragility has its origins in growth and aging. J Bone Miner Res. 2003; 18:1766-1774. [PubMed: 14584886]

15. Beck TJ, Oreskovic TL, Stone KL, et al. Structural adaptation to changing skeletal load in the progression toward hip fragility: the study of osteoporotic fractures. J Bone Miner Res. 2001; 16:1108-1119. [PubMed: 11393788]

16. Travison TG, Araujo AB, Esche GR, et al. Lean mass and not fat mass is associated with male proximal femur strength. J Bone Miner Res. 2008; 23:189-198. [PubMed: 17922610]

17. Barrett-Connor E, Kritz-Silverstein D. Does hyperinsulinemia preserve bone? Diabetes Care. 1996; 19:1388-1392. [PubMed: 8941469]

18. Thrailkill KM, Lumpkin CK Jr, Bunn RC, et al. Is insulin an anabolic agent in bone? Dissecting the diabetic bone for clues. Am J Physiol Endocrinol Metab. 2005; 289:E735-E745. [PubMed: 16215165]

19. Nyman JS, Even JL, Jo CH, et al. Increasing duration of type 1 diabetes perturbs the strengthstructure relationship and increases brittleness of bone. Bone. 2011; 48:733-740. [PubMed: 21185416]

20. Botushanov NP, Orbetzova MM. Bone mineral density and fracture risk in patients with type 1 and type 2 diabetes mellitus. Folia Med (Plovdiv). 2009; 51:12-17. [PubMed: 20232652]

21. Montagnani A, Gonnelli S, Alessandri M, et al. Osteoporosis and risk of fracture in patients with diabetes: an update. Aging Clin Exp Res. 2011; 23:84-90. [PubMed: 21743287]

22. Isidro ML, Ruano B. Bone disease in diabetes. Curr Diabetes Rev. 2010; 6:144-155. [PubMed: 20380629]

23. Schwartz AV, Sellmeyer DE. Diabetes, fracture, and bone fragility. Curr Osteoporos Rep. 2007; 5:105-111. [PubMed: 17925191]

24. de Liefde II, van der Klift M, de Laet CE, et al. Bone mineral density and fracture risk in type-2 diabetes mellitus: the Rotterdam Study. Osteoporos Int. 2005; 16:1713-1720. [PubMed: 15940395]

25. Schwartz AV, Sellmeyer DE, Ensrud KE, et al. Older women with diabetes have an increased risk of fracture: a prospective study. J Clin Endocrinol Metab. 2001; 86:32-38. [PubMed: 11231974]

26. Strotmeyer ES, Cauley JA, Schwartz AV, et al. Nontraumatic fracture risk with diabetes mellitus and impaired fasting glucose in older white and black adults: the health, aging, and body composition study. Arch Intern Med. 2005; 165:1612-1617. [PubMed: 16043679] 
27. Janghorbani M, Feskanich D, Willett WC, et al. Prospective study of diabetes and risk of hip fracture: the Nurses' Health Study. Diabetes Care. 2006; 29:1573-1578. [PubMed: 16801581]

28. Schwartz AV, Sellmeyer DE, Vittinghoff E, et al. Thiazolidinedione use and bone loss in older diabetic adults. J Clin Endocrinol Metab. 2006; 91:3349-3354. [PubMed: 16608888]

29. Monami M, Cresci B, Colombini A, et al. Bone fractures and hypoglycemic treatment in type 2 diabetic patients: a case-control study. Diabetes Care. 2008; 31:199-203. [PubMed: 18024851]

30-. Gruntmanis U, Fordan S, Ghayee HK, et al. The peroxisome proliferatoractivated receptor-gamma agonist rosiglitazone increases bone resorption in women with type 2 diabetes: a randomized, controlled trial. Calcif Tissue Int. 2010; 86:343-349. Double-blind, placebo-controlled, randomized trial showing that 6 months of rosiglitazone treatment in T2DM causes significant elevations in markers of bone resorption. [PubMed: 20354684]

31. Grey A, Bolland M, Gamble G, et al. The peroxisome proliferator-activated receptor-gamma agonist rosiglitazone decreases bone formation and bone mineral density in healthy postmenopausal women: a randomized, controlled trial. J Clin Endocrinol Metab. 2007; 92:13051310. [PubMed: 17264176]

32. Kahn SE, Zinman B, Lachin JM, et al. Rosiglitazone-associated fractures in type 2 diabetes: an Analysis from A Diabetes Outcome Progression Trial (ADOPT). Diabetes Care. 2008; 31:845851. [PubMed: 18223031]

33. Meier C, Kraenzlin ME, Bodmer M, et al. Use of thiazolidinediones and fracture risk. Arch Intern Med. 2008; 168:820-825. [PubMed: 18443256]

34. Vestergaard P. Bone metabolism in type 2 diabetes and role of thiazolidinediones. Curr Opin Endocrinol Diabetes Obes. 2009; 16:125-131. [PubMed: 19300092]

35. Golden SH, Lazo M, Carnethon M, et al. Examining a bidirectional association between depressive symptoms and diabetes. JAMA. 2008; 299:2751-2759. [PubMed: 18560002]

36. Mezuk B, Eaton WW, Albrecht S, et al. Depression and type 2 diabetes over the lifespan: a metaanalysis. Diabetes Care. 2008; 31:2383-2390. [PubMed: 19033418]

37. Karsenty G, Gershon MD. The Importance of the Gastrointestinal Tract in the Control of Bone Mass Accrual. Gastroenterology. 2011; 141:439-442. [PubMed: 21699800]

38. Yadav VK, Oury F, Suda N, et al. A serotonin-dependent mechanism explains the leptin regulation of bone mass, appetite, and energy expenditure. Cell. 2009; 138:976-989. [PubMed: 19737523]

39. Karsenty G, Oury F. The central regulation of bone mass, the first link between bone remodeling and energy metabolism. J Clin Endocrinol Metab. 2010; 95:4795-4801. Review highlighting the complex molecular pathways by which leptin mediates bone metabolism and appetite through brain signaling. [PubMed: 21051575]

40. Diem SJ, Blackwell TL, Stone KL, et al. Use of antidepressants and rates of hip bone loss in older women: the study of osteoporotic fractures. Arch Intern Med. 2007; 167:1240-1245. [PubMed: 17592096]

41. Haney EM, Chan BK, Diem SJ, et al. Association of low bone mineral density with selective serotonin reuptake inhibitor use by older men. Arch Intern Med. 2007; 167:1246-1251. [PubMed: 17592097]

42. Williams LJ, Henry MJ, Berk M, et al. Selective serotonin reuptake inhibitor use and bone mineral density in women with a history of depression. Int Clin Psychopharmacol. 2008; 23:84-87. [PubMed: 18301122]

43. Richards JB, Papaioannou A, Adachi JD, et al. Effect of selective serotonin reuptake inhibitors on the risk of fracture. Arch Intern Med. 2007; 167:188-194. [PubMed: 17242321]

44. Lewis CE, Ewing SK, Taylor BC, et al. Predictors of nonspine fracture in elderly men: the MrOS study. J Bone Miner Res. 2007; 22:211-219. [PubMed: 17059373]

45-. Goltzman D. LRP5, serotonin and bone: complexity, contradictions and conundrums. J Bone Miner Res. 2011; 26:1997-2001. Summary of the hypothesized effects of serotonin on bone metabolism and key pathways involved in this gut-mediated process. [PubMed: 21713997]

46-. Viegas M, Costa C, Lopes A, et al. Prevalence of osteoporosis and vertebral fractures in postmenopausal women with type 2 diabetes mellitus and their relationship with duration of the disease and chronic complications. J Diabetes Complications. 2011; 25:216-221. Duration of 
type 2 diabetes was strongly associated with prevalence of osteoporosis and vertebral fractures in women with T2DM, irrespective of glycemic control. [PubMed: 21458300]

47. Schwartz AV, Vittinghoff E, Sellmeyer DE, et al. Diabetes-related complications, glycemic control, and falls in older adults. Diabetes Care. 2008; 31:391-396. [PubMed: 18056893]

48. McNair P, Christensen MS, Madsbad S, et al. Hypoparathyroidism in diabetes mellitus. Acta Endocrinol (Copenh). 1981; 96:81-86. [PubMed: 7456985]

49-. Oikawa A, Siragusa M, Quaini F, et al. Diabetes mellitus induces bone marrow microangiopathy. Arterioscler Thromb Vasc Biol. 2010; 30:498-508. Bone marrow endothelial cells from mice with T1DM showed higher levels of oxidative stress, DNA damage and increased apoptosis. The marrow microenviromemt was significantly altered by systemic changes in T1DM. [PubMed: 20042708]

50. Capla JM, Grogan RH, Callaghan MJ, et al. Diabetes impairs endothelial progenitor cell-mediated blood vessel formation in response to hypoxia. Plast Reconstr Surg. 2007; 119:59-70. [PubMed: 17255657]

51. Tanko LB, Bagger YZ, Christiansen C. Low bone mineral density in the hip as a marker of advanced atherosclerosis in elderly women. Calcif Tissue Int. 2003; 73:15-20. [PubMed: 14506949]

52. Vogt MT, Cauley JA, Kuller LH, et al. Bone mineral density and blood flow to the lower extremities: the study of osteoporotic fractures. J Bone Miner Res. 1997; 12:283-289. [PubMed: 9041062]

53. Jehle PM, Jehle DR, Mohan S, et al. Serum levels of insulin-like growth factor system components and relationship to bone metabolism in Type 1 and Type 2 diabetes mellitus patients. J Endocrinol. 1998; 159:297-306. [PubMed: 9795371]

54. Hock JM, Centrella M, Canalis E. Insulin-like growth factor I has independent effects on bone matrix formation and cell replication. Endocrinology. 1988; 122:254-260. [PubMed: 3335207]

55-. Kanazawa I, Yamaguchi T, Sugimoto T. Serum insulin-like growth factor-I is a marker for assessing the severity of vertebral fractures in postmenopausal women with type 2 diabetes mellitus. Osteoporos Int. 2011; 22:1191-1198. Serum levels of IGF-1 were inversely correlated with vertebral fractures in women with T2DM. IGF-1 may be useful as a marker of vertebral fracture severity. [PubMed: 20532480]

56. van den Beld AW, de Jong FH, Grobbee DE, et al. Measures of bioavailable serum testosterone and estradiol and their relationships with muscle strength, bone density, and body composition in elderly men. J Clin Endocrinol Metab. 2000; 85:3276-3282. [PubMed: 10999822]

57. Kapoor D, Aldred H, Clark S, et al. Clinical and biochemical assessment of hypogonadism in men with type 2 diabetes: correlations with bioavailable testosterone and visceral adiposity. Diabetes Care. 2007; 30:911-917. [PubMed: 17392552]

58. Dhindsa S, Bhatia V, Dhindsa G, et al. The effects of hypogonadism on body composition and bone mineral density in type 2 diabetic patients. Diabetes Care. 2007; 30:1860-1861. [PubMed: 17416787]

59. Corona G, Monami M, Rastrelli G, et al. Type 2 diabetes mellitus and testosterone: a meta-analysis study. Int J Androl. 2010; 34:528-540. [PubMed: 20969599]

60. Baynes KC, Boucher BJ, Feskens EJ, et al. Vitamin D, glucose tolerance and insulinaemia in elderly men. Diabetologia. 1997; 40:344-347. [PubMed: 9084975]

61. Perry HM 3rd, Horowitz M, Morley JE, et al. Longitudinal changes in serum 25-hydroxyvitamin D in older people. Metabolism. 1999; 48:1028-1032. [PubMed: 10459569]

62. Pittas AG, Lau J, Hu FB, et al. The role of vitamin D and calcium in type 2 diabetes. A systematic review and meta-analysis. J Clin Endocrinol Metab. 2007; 92:2017-2029. [PubMed: 17389701]

63. Scragg R, Sowers M, Bell C, et al. Serum 25-hydroxyvitamin D, diabetes, and ethnicity in the Third National Health and Nutrition Examination Survey. Diabetes Care. 2004; 27:2813-2818. [PubMed: 15562190]

64. Aloia JF, Vaswani A, Ma R, et al. To what extent is bone mass determined by fat-free or fat mass? Am J Clin Nutr. 1995; 61:1110-1114. [PubMed: 7733036] 
65. Pluijm SM, Visser M, Smit JH, et al. Determinants of bone mineral density in older men and women: body composition as mediator. J Bone Miner Res. 2001; 16:2142-2151. [PubMed: 11697812]

66. Visser M, Kiel DP, Langlois J, et al. Muscle mass and fat mass in relation to bone mineral density in very old men and women: the Framingham Heart Study. Appl Radiat Isot. 1998; 49:745-747. [PubMed: 9569599]

67. Stewart KJ, Deregis JR, Turner KL, et al. Fitness, fatness and activity as predictors of bone mineral density in older persons. J Intern Med. 2002; 252:381-388. [PubMed: 12528755]

68-. Moseley KF, Dobrosieski DA, Stewart KJ, et al. Lean mass and fat mass predict bone mineral density in middle-aged individuals with noninsulin-requiring type 2 diabetes mellitus. Clin Endocrinol (Oxf). 2011; 74:565-571. First study describing the association between body composition and bone mineral density in men and women with uncomplicated, noninsulinrequiring T2DM. [PubMed: 21198741]

69-. Moseley KF, Dobrosielski DA, Stewart KJ, et al. Lean mass predicts hip geometry in men and women with noninsulin-requiring type 2 diabetes mellitus. J Clin Densitom. 2011; 14:332-339. First published study describing the association between hip geometry and body composition in men and women with T2DM. [PubMed: 21652249]

70-r. Kim TN, Park MS, Yang SJ, et al. Prevalence and determinant factors of sarcopenia in patients with type 2 diabetes: the Korean Sarcopenic Obesity Study (KSOS). Diabetes Care. 2010; 33:1497-1499. Sarcopenia, measured by skeletal muscle index, was more prevalent in older men and women withT2DM compared with those with normal glycemic control. [PubMed: 20413515]

71. Dominguez LJ, Barbagallo M. The cardiometabolic syndrome and sarcopenic obesity in older persons. J Cardiometab Syndr. 2007; 2:183-189. [PubMed: 17786082]

72. Baumgartner RN, Stauber PM, Koehler KM, et al. Associations of fat and muscle masses with bone mineral in elderly men and women. Am J Clin Nutr. 1996; 63:365-372. [PubMed: 8602594]

73. Reid IR, Plank LD, Evans MC. Fat mass is an important determinant of whole body bone density in premenopausal women but not in men. J Clin Endocrinol Metab. 1992; 75:779-782. [PubMed: 1517366]

74. Reid IR, Ames R, Evans MC, et al. Determinants of total body and regional bone mineral density in normal postmenopausal women: a key role for fat mass. J Clin Endocrinol Metab. 1992; 75:4551. [PubMed: 1619030]

75. Zhao LJ, Jiang H, Papasian CJ, et al. Correlation of obesity and osteoporosis: effect of fat mass on the determination of osteoporosis. J Bone Miner Res. 2008; 23:17-29. [PubMed: 17784844]

76. Confavreux CB, Levine RL, Karsenty G. A paradigm of integrative physiology, the crosstalk between bone and energy metabolisms. Mol Cell Endocrinol. 2009; 310:21-29. [PubMed: 19376193]

77. Reseland JE, Syversen U, Bakke I, et al. Leptin is expressed in and secreted from primary cultures of human osteoblasts and promotes bone mineralization. J Bone Miner Res. 2001; 16:1426-1433. [PubMed: 11499865]

78. Thomas T, Gori F, Khosla S, et al. Leptin acts on human marrow stromal cells to enhance differentiation to osteoblasts and to inhibit differentiation to adipocytes. Endocrinology. 1999; 140:1630-1638. [PubMed: 10098497]

79. Jurimae J, Jurimae T, Leppik A, et al. The influence of ghrelin, adiponectin, and leptin on bone mineral density in healthy postmenopausal women. J Bone Miner Metab. 2008; 26:618-623. [PubMed: 18979162]

80. Jang M, Mistry A, Swick AG, et al. Leptin rapidly inhibits hypothalamic neuropeptide Y secretion and stimulates corticotropin-releasing hormone secretion in adrenalectomized mice. J Nutr. 2000; 130:2813-2820. [PubMed: 11053526]

81. Ducy P, Amling M, Takeda S, et al. Leptin inhibits bone formation through a hypothalamic relay: a central control of bone mass. Cell. 2000; 100:197-207. [PubMed: 10660043]

82. Kanazawa I, Yamaguchi T, Sugimoto T. Baseline serum total adiponectin level is positively associated with changes in bone mineral density after 1-year treatment of type 2 diabetes mellitus. Metabolism. 2010; 59:1252-1256. [PubMed: 20045535] 
83. Kontogianni MD, Dafni UG, Routsias JG, et al. Blood leptin and adiponectin as possible mediators of the relation between fat mass and BMD in perimenopausal women. J Bone Miner Res. 2004; 19:546-551. [PubMed: 15005840]

84. Kanazawa I, Yamaguchi T, Yamamoto M, et al. Relationships between serum adiponectin levels versus bone mineral density, bone metabolic markers, and vertebral fractures in type 2 diabetes mellitus. Eur J Endocrinol. 2009; 160:265-273. [PubMed: 18996964]

85. Wang X, Shen X, Li X, et al. Age-related changes in the collagen network and toughness of bone. Bone. 2002; 31:1-7. [PubMed: 12110404]

86. Viguet-Carrin S, Roux JP, Arlot ME, et al. Contribution of the advanced glycation end product pentosidine and of maturation of type I collagen to compressive biomechanical properties of human lumbar vertebrae. Bone. 2006; 39:1073-1079. [PubMed: 16829221]

87m. Saito M, Marumo K. Collagen cross-links as a determinant of bone quality: a possible explanation for bone fragility in aging, osteoporosis, and diabetes mellitus. Osteoporos Int. 2010; 21:195-214. Collagen cross-link formation that occurs with age and T2DM may mediate bone fragility. [PubMed: 19760059]

88. Schwartz AV, Garnero P, Hillier TA, et al. Pentosidine and increased fracture risk in older adults with type 2 diabetes. J Clin Endocrinol Metab. 2009; 94:2380-2386. [PubMed: 19383780]

89. Yamamoto M, Yamaguchi T, Yamauchi M, et al. Serum pentosidine levels are positively associated with the presence of vertebral fractures in postmenopausal women with type 2 diabetes. J Clin Endocrinol Metab. 2008; 93:1013-1019. [PubMed: 18160470]

90. Zhou S, Greenberger JS, Epperly MW, et al. Age-related intrinsic changes in human bone-marrowderived mesenchymal stem cells and their differentiation to osteoblasts. Aging Cell. 2008; 7:335343. [PubMed: 18248663]

91. Sethe S, Scutt A, Stolzing A. Aging of mesenchymal stem cells. Ageing Res Rev. 2006; 5:91-116. [PubMed: 16310414]

92. Conboy IM, Conboy MJ, Wagers AJ, et al. Rejuvenation of aged progenitor cells by exposure to a young systemic environment. Nature. 2005; 433:760-764. [PubMed: 15716955]

93. Ben David D, Reznick AZ, Srouji S, et al. Exposure to pro-inflammatory cytokines upregulates MMP-9 synthesis by mesenchymal stem cells-derived osteoprogenitors. Histochem Cell Biol. 2008; 129:589-597. [PubMed: 18274772]

94. Lacey DC, Simmons PJ, Graves SE, et al. Proinflammatory cytokines inhibit osteogenic differentiation from stem cells: implications for bone repair during inflammation. Osteoarthritis Cartilage. 2009; 17:735-742. [PubMed: 19136283]

95-. Cramer C, Freisinger E, Jones RK, et al. Persistent High Glucose Concentrations Alter the Regenerative Potential of Mesenchymal Stem Cells. Stem Cells Dev. 2010; 19:1875-1884. Adipose-derived mesenchymal stem cells demonstrated reduced osteogenic potential when taken from patientss with T2DM. [PubMed: 20380516]

96. Kume S, Kato S, Yamagishi S, et al. Advanced glycation end-products attenuate human mesenchymal stem cells and prevent cognate differentiation into adipose tissue, cartilage, and bone. J Bone Miner Res. 2005; 20:1647-1658. [PubMed: 16059636]

97. Takagi M, Kasayama S, Yamamoto T, et al. Advanced glycation endproducts stimulate interleukin-6 production by human bone-derived cells. J Bone Miner Res. 1997; 12:439-446. [PubMed: 9076587]

98. Kassem M. Cellular and molecular effects of growth hormone and estrogen on human bone cells. APMIS Suppl. 1997; 71:1-30. [PubMed: 9357492]

99. Schwartz AV, Vittinghoff E, Bauer DC, et al. Association of BMD and FRAX score with risk of fracture in older adults with type 2 diabetes. JAMA. 2011; 305:2184-2192. [PubMed: 21632482]

100. Rauch F. Bone biopsy: indications and methods. Endocr Dev. 2009; 16:49-57. [PubMed: 19494660]

101. Brandi ML. Microarchitecture, the key to bone quality. Rheumatology (Oxford). 2009; 48(Suppl 4):iv3-iv8. [PubMed: 19783591]

102. Liu XS, Cohen A, Shane E, et al. Bone density, geometry, microstructure, and stiffness: Relationships between peripheral and central skeletal sites assessed by DXA, HR-pQCT, and cQCT in premenopausal women. J Bone Miner Res. 2010; 25:2229-2238. [PubMed: 20499344] 
103- Cohen A, Dempster DW, Muller R, et al. Assessment of trabecular and cortical architecture and mechanical competence of bone by high-resolution peripheral computed tomography: comparison with transiliac bone biopsy. Osteoporos Int. 2010; 21:263-273. There are few significant associations between measures of bone microarchitecture as determined by bone biopsy versus HR-pQCT. [PubMed: 19455271]

104-. Burghardt AJ, Issever AS, Schwartz AV, et al. High-Resolution Peripheral Quantitative Computed Tomographic Imaging of Cortical and Trabecular Bone Microarchitecture in Patients with Type 2 Diabetes Mellitus. J Clin Endocrinol Metab. 2010; 95:5045-5055. First study to use HR-pQCT to compare bone microarchitecture in patients with and without T2DM. [PubMed: 20719835]

105-. Diez-Perez A, Guerri R, Nogues X, et al. Microindentation for in vivo measurement of bone tissue mechanical properties in humans. J Bone Miner Res. 2010; 25:1877-1885. Description of microindentation, a novel and minimally-invasive technique for measuring bone toughness. [PubMed: 20200991]

106. Yamaguchi T, Yamamoto M, Kanazawa I, et al. Quantitative ultrasound and vertebral fractures in patients with type 2 diabetes. J Bone Miner Metab. 2011; 29:626-632. [PubMed: 21437613]

107. Akin O, Gol K, Akturk M, et al. Evaluation of bone turnover in postmenopausal patients with type 2 diabetes mellitus using biochemical markers and bone mineral density measurements. Gynecol Endocrinol. 2003; 17:19-29. [PubMed: 12724015]

108. Gerdhem P, Isaksson A, Akesson K, et al. Increased bone density and decreased bone turnover, but no evident alteration of fracture susceptibility in elderly women with diabetes mellitus. Osteoporos Int. 2005; 16:1506-1512. [PubMed: 15824889]

109. Okazaki R, Totsuka Y, Hamano K, et al. Metabolic improvement of poorly controlled noninsulindependent diabetes mellitus decreases bone turnover. J Clin Endocrinol Metab. 1997; 82:29152920. [PubMed: 9284719]

110. Vestergaard P, Rejnmark L, Mosekilde L. Are antiresorptive drugs effective against fractures in patients with diabetes? Calcif Tissue Int. 2011; 88:209-214. Antiresorptive medications like bisphosphonates and raloxifene appear to decrease fracture risk in men and women with T2DM as effectively as they do in those without diabetes. [PubMed: 21161194] 


\section{KEY POINTS}

- Despite normal to high bone density, men and women with type 2 diabetes are at increased risk for fracture.

- Medications like thiazolidinediones may increase fracture risk in persons with type 2 diabetes.

- Lean and fat mass may differentially affect bone strength in type 2 diabetes mellitus.

- Fracture risk assessment is challenging in men and women with type 2 diabetes given that dual X-ray absorptiometry does not necessarily predict fracture risk. 


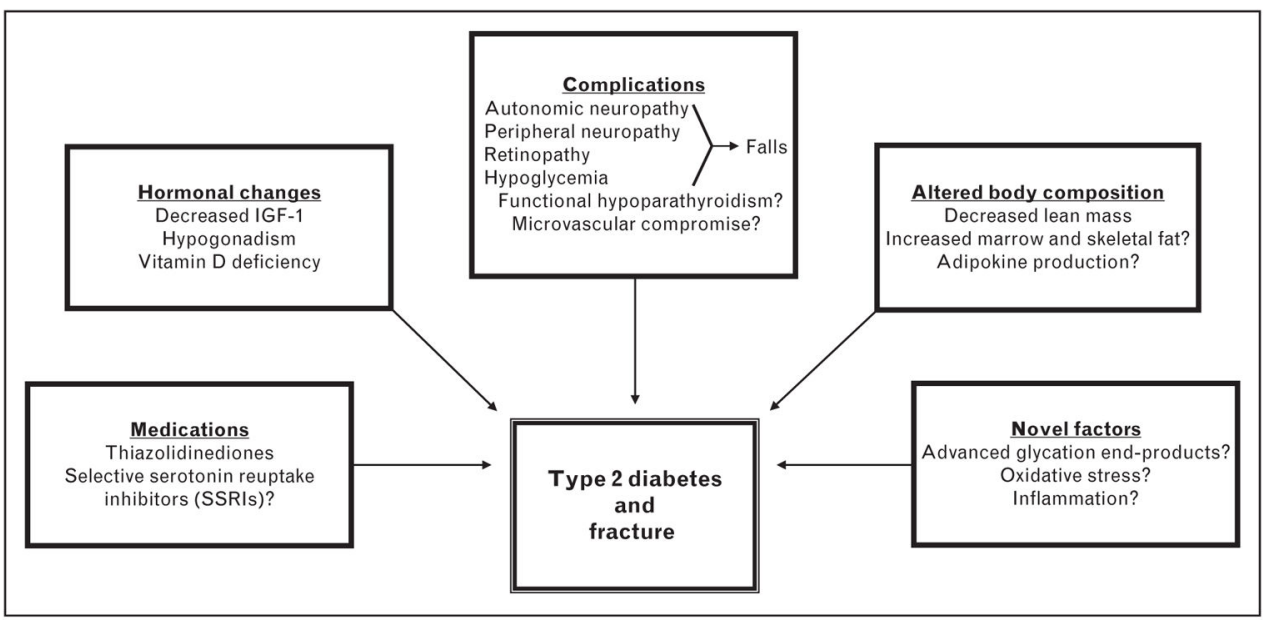

FIGURE 1.

Proposed mechanisms of bone fragility in type 2 diabetes mellitus. 